\title{
Editorial
}

\section{Police, Policing and COVID-19 Pandemic}

The past almost two years have brought many changes to our lives. The COVID-19 pandemic was announced by the wHO on 11 March 2O2O, and social life soon changed significantly. Schools, universities, and kindergartens were closed down and many other work-related activities moved to the workfrom-home platform as stay-at-home- and curfew measures were adopted by almost all governments while others decided in favour of a much more liberal approach. Some industries or sectors thereof were badly affected, others, particularly the tourism and hospitality sectors, collapsed. This editorial is aimed at complementing the previous editorials by Estella Baker (2020) and Nina Peršak (2O2O). In social control activities, the police have crucial roles in providing people with security and safety, maintaining public order, and investigating crime. On top of this, the police play a vital role in community policing activities. External perspectives regarding policing and the police are critical, and so are the internal ones giving rise to questions about the role of the police in the COVID-19 pandemic. Police organisations' adaptation to the new circumstances in terms of caring for police officers' health, long hours of police work, pressures by civil criticism of the police in controlling offenders for neither wearing protective masks or ignoring governmental regulations with a view to curbing the spread of the virus, such as the curfew and prohibition of gathering in public places, highlighted several challenges.

This years' CEPOL Research and Science Conference dealt with the role of the police in the times of the COVID-19 pandemic. The conference organisers were CEPOL, the European Union Agency for Law Enforcement Training, and the Mykolas Romeris University of Lithuania. Speakers were mostly from Europe and some from the USA and South Africa. In total, more than $55^{\circ}$ participants registered for the conference. The conference was organised in six 
tracks featuring presentations covering specific essential topics, training and education, management and organisation, health and safety, changing crime patterns, and public relations and public order. The conference spanned three days from 5-7 May 2021 and was held online (CEPOL, 2021). Selected papers will be published in the CEPOL - European Law Enforcement Bulletin. One purpose of this editorial is to discuss some critical insights presented at the conference because the role of the police has been, in addition to health services, one of the most crucial ones. First, the health crisis also became a security issue. Second, the police as one of the "emergency services" of the state were under pressure to adapt to new circumstances rapidly. Each topic requires special attention and deserves an in-depth study due to the impact the police have on people in police procedures and subsequently in criminal and other proceedings following the initial police contacts with (potential) offenders, victims, and other people.

The first group of reflections focused on changes in police training during the covid-19 pandemic and after it. Almost all police training modules moved to online teaching. The main questions were related to the quality of education, quality of knowledge acquired, and the applicability of online training of police recruits. One of the crucial questions was directed toward testing of knowledge and training in police ethics. Reflections also focused on the problems in other fields of education and training, causing even more workload for the trainers and lecturers than under normal circumstances. The outcomes of the quality of police training will be known soon. Some solutions of online training are also applicable in future endeavours, especially in online teaching in small groups.

The second group of debates dealt with police management and organisation in a crisis. The leading topics dealt with coordination of police activities, coordination with other organisations, and security operations. A specific challenge was dealing with fake news about the work of the police. The lessons learnt during the pandemic of COVID-19 were numerous. Rich and intensive experiences related to everyday policing, changing criminal investigation procedures due to health risks of police officers and detectives, police intelligence sharing, policing in times of uncertainty and ambiguity, and interventions, especially in domestic violence and innovations, are just a few among them.

The third group of discussions included issues related to health and safety for law enforcement, focusing on the mental health of police officers, police trainees, the psychosocial impact of policing, stress and coping strategies of police, and police officers' well-being during the CoviD-19 pandemic, the impact of the CoviD-19 pandemic on the quality of police work, and police cooperation. 
The fourth group presented changing patterns of crime and problems related to criminal investigation. In this group of presentations, national perspectives showed that the reported and recorded everyday property- and violent crime decreased while cybercrime increased. The changing nature of crime and general social circumstances impacted the investigative work of the police. The reflections focused on serious traffic offences, strange sex offences, child exploitation, social media criminality, artificial intelligence impact on security and safety, and evolution of cyber-attacks during the CoviD-19 pandemic.

The fifth group dealt with public relations and public order. In this group, everyday policing was discussed, especially the interventions in public disorder and those in policing public demonstrations held against governments, their decisions regarding the COVID-19 restriction measures, such as stay-athome and curfew, as well as needless disciplining of people. On the one hand, changing the police image in people's perceptions of the police in the pandemic times, police discretion, curfew, quarantine, health security measures and populist pressures, and the negative public opinion were frequent subjects of the debate. On the other hand, community policing as a promising strategy and the present modality of policing was also presented as a viable priority after the pandemic.

The featured presentations focused on each of the five groups' discussions, portraying critical perspectives of European police organisational changes during the CoviD-19 pandemic, cybercrime extortions in the translational landscape, fraud, pandemic and crime control, organised crime infiltration in the CovID-19 economy, internal security of the EU, international perspectives on police training, day-to-day policing across the Atlantic, as well as policing, security and the COVID-19 crisis - all in a comparative EU perspective.

As the European Journal of Crime, Criminal Law and Criminal Justice covers topics also presented at this year's CEPOL conference, Monica de Boer's discussion on the role of the police today deserves special attention due to the European and global dimensions. According to Laufs and Waseem (2020), COVID-19 brought unforeseen and unprecedented challenges to policing. These challenges are related to security and governance, policing and law enforcement, changing crime patterns, and public order issues. Security governance during the pandemic challenges includes: crisis management (health crisis as a security problem, state executive power, reduced role of parliaments in crisis management), the role of executive power (lack of parliamentary scrutiny, limited transparency, prevalence of performative speech), and legitimacy crises (governments in charge; breach of the principle of division of powers may be a threat to democracy - no checks and balances). Policing and law enforcement challenges are related to public 
order management, criminal investigation, community policing, and crisis management. In this regard, the police faced public activism (protests, demonstrations against masks, governments and their decisions regarding restriction of movement, curfews) and revolts (not only physical but also virtual - online revolts). It is also necessary to emphasise many social tensions before the COVID-19 crisis, and some emerged during the pandemic. The police find themselves "sandwiched" between vertical governance and professional discretion, and a high level of civil compliance. Although the police forces should follow the rule of law, cases of unlawful force were documented in imposing lockdown measures on people nether offering any resistance nor constituting a significant threat. These problems occurred in the context of police identity checks because the police focused disproportionately on radicalised groups. Coercive measures were not always used as a matter of last resort, causing a problem of proportionality in the use of police powers, thus challenging police legitimacy.

Regarding criminal investigation, the police also experienced many challenges. As stated in Halford et al. (2021), the relatively short-term rapid changes in crime experienced during the COVID-19 pandemic appear consistent with the explanation offered for the longer-term international crime drop, as well as with the increase in cybercrime, fraud, and other new crimes that emerged as a result of increased crime opportunities. Some of these findings were supported not only in the research by other authors in their national analyses (Meško and Urbas, 2021) and in international research (Nivette et al., in print) but also at this conference, among others by Michael Levi (e.g., smishing texts messages, pet purchase, scam e-mails, fake licenses, phishing e-mails, holiday scams, fake tax e-mails, smishing e-mails, shopping scams, and parcel scams) and David Wall (changing cybercrime attack vectors: shift to keystone cybercrimes, from attacking individuals to organisations, using affiliate business model, using blended cybercrime tactics, using human-operated systems, using facilitators and business model), discussing the changing patterns of cybercrime and frauds during the CoviD-19 pandemic. It is necessary to raise attention to domestic violence and public sector corruption, especially regarding public procurement practices in buying protective and medical equipment, and public expenditure to post-covid recovery funds, fraud related to healthcare products and supplies, and insufficient compliance with the public procurement legislation.

A well-known panacea - community (oriented) policing mostly proclaimed by the police organisations as the leading philosophy, strategy, tactic, and method of (democratic) policing, though simultaneously the one most diversely implemented - has also been discussed as an effective policing option 
in the post-pandemic period. In these coviD-19 times, community (oriented) policing has suffered due to limited physical contacts of the police with residents, inadequate messaging and communication with citizens (i.e., a lack of national communication infrastructure), insufficient variation between styles of policing, lack of accountability mechanisms, police infringing on civil liberties, the disproportionate targeting of minorities, over- and under-policing, and low emphasis on self-policing (i.e., responsibilisation, informal control). Similarly, Terpstra, de Maillard, Salet and Roche (2021) reflect upon policing in the corona crisis.

To conclude, the presented and discussed CEPOL conference covering timely and topical problems of European and broader policing during the pandemic was organised online for the first time. In the past year, many of us got used to online conferencing enabling us to attend even more international scientific events than in the past. The missing components of online meetings are personal contact and social networking. In the past year, though, such conferencing provided by the advances of modern technology helped us remain connected and continue to work with our colleagues, researchers, and students. The conference opened new avenues for research of good practices and of needs for police practice improvements in Europe, impacting social life in general and the criminal justice system specifically. It is also necessary to think about what the COVID-19 pandemic brought the police and governments and how they will adapt to the new post-COVID-19 social circumstances. In this case, a promising idea for comparative research on European police organisational changes was presented by Jon Maskaly, Sanja Kutnjak Ivkovich and Peter Neyroud (see also Maskaly, Kutnjak Ivković and Neyroud, 2021), focusing on policing in the COVID-19 pandemic asking crucial questions regarding policing: what has changed, how much has it changed, and what are the anticipated consequences of these changes? As their study uses world governance indicators, policing should be studied as a crucial element of governance in democratic countries of the European Union after the end of the COVID-19 pandemic, as well. At this moment, it is difficult to predict what the main changes regarding European policing will be once the CovID-19 pandemic is over.

It has to be mentioned that CEPOL is implementing its mission by facilitating policing research and cooperation between police practitioners and researchers. Dissemination of knowledge and skills adapted to new social challenges is noteworthy. More interest of policymakers and representatives from other sectors of public life in Europe is missing at the CEPOL Research and Science Conferences. Again, it has been noticed that the police keep a high level of responsibility and strive to solve problems in unpredictable social and politically flammable circumstances. The majority of the police still do their work while following the ideals of protecting and serving people legally and 
legitimately, improving education and training, adjusting management, taking care of police-public relations, and working with communities.

\author{
Gorazd Meško \\ Professor of Criminology, Faculty of Criminal Justice and Security, University \\ of Maribor, Ljubljana, Slovenia \\ gorazd.mesko@fvv.uni-mb.si
}

\title{
References
}

Baker, E. (2020). The Crisis that Changed Everything: Reflections on COvid-19. European Journal of Crime, Criminal Law and Criminal Justice, 4(28), 311-331.

CEPOL (2O21). CEPOL Research and Science Conference 2021. Retrieved from https:// conference.cepol.europa.eu/cepol-online-conference-2021/talk/.

Halford, E., Dixon, A., Farrell, G. et al. Crime and coronavirus: social distancing, lockdown, and the mobility elasticity of crime. Crime Sci 9, 11 (2020). https://doi. org/10.1186/s40163-02O-00121-w

Laufs, J., and Waseem, Z. (2020). Policing in pandemics: A systematic review and best practice for police response to CoviD-19. International Journal of Disaster Reduction. doi: 10.1016/j.ijdrr.2020.101812.

Maskaly, J., Kutnjak, Ivković, S. and Neyroud, P. (2021). Policing the covid-19 Pandemic: Exploratory Study of the Types of Organizational Changes and Police Activities Across the Globe. International Criminal Justice Review, 2opp. doi: https://doi. org/10.1177/10575677211012807.

Meško, G., and Urbas, V. (2021). Delo policija na področju preiskovanja kriminalitete v Sloveniji v času covida-19s poudarkom na prvem valu epidemije covida-19 spomladi 2020 [Police Work in the Field of Crime Investigation during COVID-19 in Slovenia with Emphasis on the First Wave of the Epidemic in Spring 2020]. Revija za kriminalistiko in kriminologijo, 72(1), 21-35.

Nivette, A. et al. (in print). A global analysis of the impact of covid-19 stay at home restrictions on crime. Nature Human Behaviour.

Peršak, N. (2O2O). COVID-19 and the Social Responses thereto: Penal and Criminological Lessons, Human Rights and Rule of Law Implications, European Journal of Crime, Criminal Law and Criminal Justice, 3(28), 205-216.

Terpstra, J., de Maillard, J., Salet, R., and Roche, S. (2021). Policing the corona crisis: A comparison between France and the Netherlands. International Journal of Police Science and Management. doi: 10.1177\%2F1461355720980772. 